\title{
Knowledge on Maternal-Fetal Transmission of HIV in Pregnant Women
}

\author{
Ulty Desmarnita, Deswani", Paula Krisanti \\ Nursing Department of Health Polytechnic of Ministry of Health Jakarta III \\ Jl. Arteri JORR Jatiwarna Pondok Melati, Bekasi, Indonesia \\ *Corresponding author's email: ultyhanafi [AT] yahoo.co.id
}

\begin{abstract}
HIV or Human Immunodeficiency Virus is a virus affecting immune system consisting of white blood cells and lymphocytes called "T-4 cell" or "CD-4 cell" which fights infection. The fetus may easily contract the disease from mother with HIV and inflamed placenta. The study aimed to identify knowledge on mother-to-child transmission of HIV in pregnant women with HIV. The study design was quantitative with descriptive phenomenology approach and analysis by Colaizzi method. The study involved 9 participants. This study identified 7 themes including: 1) knowledge about HIV, 2) treatment of pregnant mothers with HIV during, 3) sources that support prevention of HIV, 4) information sources, 5) barrier in prevention, 6) how to deal with barrier, and 7) impact of HIV on fetus. Participants demonstrated inadequate level of knowledge about HIV transmission to fetus based on the identified themes. These findings may be beneficial for further studies and in development of health service programs for pregnant women, especially pregnant women with HIV.
\end{abstract}

Keywords- Fetus, HIV, knowledge, pregnant women

\section{INTRODUCTION}

Human Immunodeficiency Virus is a virus affecting the immune system. The virus impairs the function of immune cells, resulting in increased susceptibility to opportunity infections, cancer, or other diseases [1]. The disease can be transmitted through exchange of various body fluids, such as blood, semen, and vaginal secretions. Pregnant women with HIV may also transmit the disease to the fetus during pregnancy, childbirth, or breastfeeding [1].

WHO declare HIV as a global concern that tends to rise in numbers [2]. HIV has claimed over than 940.000 lives globally in 2017. UNAIDS stated that in 2016, Indonesia had 48,000 new HIV infections and 38,000 AIDS related deaths [3]. They further explained that 3200 children contracted the disease due to mother-to-child transmission. Ministry of Health reported that there were 10376 new cases of HIV up to March 2017 [4]. Regions with the highest HIV prevalence included Jakarta, East Java, Papua, West Java, and Central Java.

Number of women with HIV steadily rises over the year. It is also followed by number of males having unsafe sexual intercourse which will eventually transmit disease to their female counterparts. Ministry of Health reported that there were 15,717 pregnant women with HIV in Indonesia in 2012 [5]. The number was expected to rise up to 19,636 by 2016. The transmission of HIV from mother to children may be prevented by increasing awareness and knowledge on HIV/AIDS among mothers. However, a study suggested that only $28.3 \%$ of women had comprehensive knowledge on HIV/AIDS [6].

The rise in prevalence associated with increasing case of drug abuse, free sex behaviors are worsened by inadequate knowledge on maternal-fetal transmission of HIV among pregnant women with HIV. Therefore, authors were concerned to identify knowledge on mother-to-child transmission of HIV in pregnant women. The study was conducted with aim to prevent further transmission of HIV.

\section{METHODS}

The study design was qualitative with descriptive phenomenology approach. The study aimed to identify knowledge on mother-to-child transmission of HIV in pregnant women. The study was conducted at Puskesmas Matraman in East Jakarta from April to October 2014. The study involved 9 pregnant women who were selected through purposive sampling technique followed by saturation process.The inclusion criteria of participant were pregnant woman who was able to convey knowledge about HIV transmission to fetus, speak Indonesian, cooperative, and willing to engage in full study and signed a written informed consent. 


\section{RESULTS \& DISCUSSION}

\subsection{HIV Disease}

\subsubsection{Definition of HIV}

Participants did not able to define HIV. Most participants described HIV as an infectious disease. There were four participants described it as a sexually transmitted disease.

"HIV? I only know it as a sexually transmitted disease." (P5)

"HIV is kind of transmitted disease, right?" (P7)

"A communicable disease and must be regularly checked" (P8)

"HIV? I know. Isn’t it an infectious disease? Also a sexual disease, right? That is all." (P9)

Furthermore, one participant mentioned HIV as AIDS and caused by virus,

"It is a type of virus. That is all." (P2)

Only one participant mentioned it is caused by virus. However, it was not clearly described that HIV is a disease caused by Human Immunodeficiency Virus, a virus that weakens immune system. People affected by this virus will be susceptible to infection. HIV attacks particular white blood cells called T-lymphocytes [7].

\subsubsection{Cause of HIV}

HIV is caused by Human Immunodeficiency Virus. It could be understood from participants' statements that they only recognized how the disease was transmitted, but not its definite cause. Some participants mentioned that HIV was caused by sex and sharing needles, the statements were as follows:

"from sex or free sex" (P1)

"Err, from sexual intercourse." (P2)

"HIV is usually caused by sex and also needle use. That is all I know." (P3)

"I suppose it is caused by free sex and sharing needle." (P5)

"Possibly from sexual engagement and bacteria, may be?" (P7)

"Well, it is commonly transmitted via sweat and free sex. That is all" (P8)

"The cause is free sex, blood transfusion and careless use of needle, as far as I know" (P9)

There were only two participants stated that they did not know the cause of HIV.

"I have no idea what causes it" (P4)

"I don't know" (P6)

In relation to participant's characteristics, there was no association with educational level as it was more likely that they were not exposed to the right information about the cause of HIV.

\subsubsection{Clinical manifestations of HIV}

All participants were not aware of signs and symptoms of HIV, as indicated by following statements:

"HIV signs and symptoms? I'm not sure." (P1)

"I have no idea." (P2)

"Err, I am not really sure, maybe gradual decrease in health condition?" (P3)

"I don’t know." (P4)

This revealed inadequate information among participants that did not associate with their characteristics, including age, level of education, and employment status. This finding contradicted a study on correlation between mother's level of education and knowledge about breastfeeding with longer exclusive breastfeeding for infants aged 6-24 months in East Java, which revealed higher education level resulted in higher level of knowledge on breastfeeding among mothers [8].

\subsubsection{Prevention}

Participants described ways to prevent HIV is by maintaining personal hygiene and being faithful to partner, as implied by these statements:

"A way to prevent it is may be by keeping distance with HIV-infected person." (P1)

"To maintain health condition, because HIV is from the blood, right? And what else? Then socialization to maintain health..."(P2)

"To prevent it is by maintaining healthy lifestyle." (P3)

"We need to be aware. That's it. I don't know much about HIV." (P4)

"To prevent it is by keeping the hygiene. Keep hygiene and being faithful to partner." (P5)

"Avoid free sex. If someone was diagnosed with HIV, it is okay get too close but no touch if possible." (P8) 
Two participants answered the question with a place to seek medical help or medication.

"To seek medical help to hospital or health center." (P6)

"To seek help to hospital or closest health center." (P7)

Some participants conveyed ways to prevent HIV by avoiding promiscuity, used needle, and use of condom.

"By avoiding free sex, and careless use of needle, as well as using condom during sex." (P9)

"Avoid free sex. If someone was diagnosed with HIV, it is okay get too close but no touch if possible..." (P8)

The statements above are yet to elaborate all means of HIV transmission. Generally, HIV is transmitted by sexual intercourse, blood transfusion, and sharing needles; however, it may also be transmitted from mother to her infant during pregnancy, delivery, and lactation. Pregnant women may contract HIV through previous sexual intercourse with a partner who was infected with HIV, blood transfusion, and needle sharing among drug addicts [9].

\subsubsection{Source of knowledge}

Most participants obtained information about HIV from sources such as television, school seminars, internet and healthcare professionals.

"I only heard a little about it." (P1)

"I don't know yet" (P2)

"I had once attended a seminar about HIV. A long time ago. If I recall it right, it was when my child attended PAUD here, in Depsos." (P3)

"I once heard somebody said HIV was this and that, malignant, incurable. That is all." (P4)

"From television and reading articles." (P5)

"I had once heard about HIV when visiting someone in Gatot Subroto hospital, that someone was contracted with HIV. He was so thin. That's it. Nothing else" (P6)

"I know it from browsing the internet during my school years." (P7)

"From television and health center when I had to undergo a blood test." (P8)

"From television, people, and other media." (P9)

The finding was similar to Khachatryan's study result [10] which revealed that nearly all study participants obtained information about sexually transmitted disease and HIV from television, while other participants obtained it from magazine and newspapers, and one participant was provided with the information from a nurse.

\subsection{Treatment of $\mathrm{HIV}$}

\subsubsection{Treatment}

Majority of participants did not understand how to take care of pregnant women with HIV, as suggested by following remarks:

"We should avoid the virus." (P1)

"I don't know." (P2)

"I am afraid I don't know much about it." (P3)

"I have no idea how to take care of people with HIV." (P4)

"Just give them the medicine and don't excommunicate them." (P5)

It is very worrying because according to Kanabus \& Nobel's study [11], without a proper treatment, around 15- 30\% of babies born to HIV positive mothers would contract HIV during pregnancy and delivery and 5-20\% of them would be infected during breastfeeding.

\subsubsection{Place for Treatment}

All participants were able to identify where the mother with HIV should get the treatment, as suggested by following statements

"I think they should go to hospital perhaps" (P1, P2, P3, P4, P6, and P7)

"I think they would be referred to hospital by the Health Center." (P5, P8, and P9)

The statements suggested that they did not understand treatment of HIV. Treatment for pregnant women with HIV included 1). Integrated ANC services which consisted of monitoring physical conditions and development of the fetus, as well as their CD4 value. Counseling service is also provided to encourage the expecting mothers to stay motivated, be well-spirited, to accept her unborn baby, and adhere to the regimen and access health services when there are physical or psychological problems. 2). Antiretroviral therapy. ARV therapy is essential to reduce the risk of HIV transmission from mother to her fetus with aim to eliminate the virus [9]. 


\subsection{Support system}

An understanding of the source of support for pregnant women with HIV is necessary so they would be able to identify where to seek for professional help. It is also necessary to identify the person whom participants ask for help for her treatment. All participants demonstrated proper understanding of source of support, as revealed by following participants:

"To obstetrics and gynecologist perhaps." (P1)

"To officers at community health center." (P4)

"To family. No one else. Family is provides her with love and support." (P6)

"To the husband as the closest person." (P8)

Support for pregnant women with HIV should be provided by their closest individuals such as husband, parents, and friends. Health workers also play important role to provide solutions for their problem. The existence of support system is critical so the expecting mothers would stay motivated and able to avoid long term distress as well as stigma.

\subsection{Source of Information}

It is fundamental to recognize sources of information in pregnant women with HIV so they would be able to identify and comprehend where to look for information on HIV treatment during pregnancy. The following remarks described how participants accessed the information on HIV.

"From attending seminar." (P3)

"I heard it from health education provided by the physician that HIV is contagious" (P4)

"From talking with my neighbors." (P6)

The findings supported Sechabe's study [12] which stated that women should be given the correct information to help them make decisions about their reproductive lives, especially in the issue of safe sex, nutrition, support, alternative, therapies, termination of pregnancy and medical intervention to reduce the risk of HIV transmission from mother to her fetus.

\subsection{Barriers}

Pregnant women with HIV may encounter barrier such as stigma from society or health professionals. Following expressions indicated stigma on HIV-pregnant women:

"I feel sorry for them" (P1)

"I think they are harmful for us" (P2)

"It will definitely bring negative impacts" (P4)

"I had experienced it once along with my neighbors in a health center. An officer looked disgusted. She looked afraid to get infected by my neighbor. I felt sorry for her." (P5)

This finding support Toivo's study [13] which stated that the main reason participants did not attend prenatal care and HIV screening was because of attitude of health workers. They outlined that the nurses were very rude and did not maintain the confidentiality of patients. They felt unsupported for undergoing treatment and were confident that nurses disclosed their disease to others.

\subsection{Dealing with Barrier}

Pregnant women with HIV required support from relatives, society, and health professional to deal with barriers which they face during pregnancy. They also required to be prepared mentally, patience, and complying with the treatment, as suggested by following statements:

"Her family should not avoid her." (P1)

"To keep providing her with unwavering support to recover, take the medicine, and stay motivated." (P3)

"The family, relative, and neighbor should provide her with moral support. She also needs to see the physician." 


\subsection{Impact of HIV on fetus}

Some of participants were not able to describe impact of HIV on fetus as indicated by following remark:

"I don’t really know." (P3)

However, other participants were able to describe how HIV may affect the fetus, as revealed below:

"It should be contagious. I don't know how but the fetus may contract HIV.” (P6)

"I think the consequence is the fetus would grow as usual. However, he should take the medicine once he was born until it is truly cured." (P7)

The study findings corresponded with Kumar and St John's study [14] on knowledge, attitude and sexual relations in women with HIV in Barbados which revealed that nearly all participants did not know that they might transmit HIV to their babies and the medication they took may prevent HIV transmission to their babies. It also revealed differences in interpretation and knowledge of HIV transmission from mother to fetus among participants. Their statements indicate a lack of knowledge on HIV transmission from mother to fetus, including how to care for pregnant women with HIV. The study also showed that participants required supports from the husband, parents or relatives, neighbor, society, and health care professionals such as nurses and doctors. Particularly for health workers, participants revealed that they should not conduct such stigma toward HIV patients by avoiding or being afraid of them.

It is also implied that participants need proper knowledge on HIV transmission to the fetus and its prevention. However, the aforementioned studies indicated that it is not enough to just provide health education for pregnant women with HIV. Therefore, interventions with cognitive and psychological approach should be developed to reduce risk of HIV transmission.

\section{ACKNOWLEDGEMENT}

Authors would like to thank all parties involved in this study.

\section{REFERENCES}

[1] World Health Organization, Fact Sheets on Sustainable Development Goals: Health Targets HIV, World Health Organization Regional Office for Europe, Denmark, 2015.

[2] World Health Organization, HIV/AIDS, Accessed from http://www.who.int/news-room/fact-sheets/detail/hiv-aids, 2017.

[3] United Nations for AIDS, Data/Indonesia, Accessed from http://www.unaids.org/en/regionscountries/countries/Indonesia, 2016

[4] Kementerian Kesehatan, Perkembangan HIV AIDS dan PIMS di Indonesia, Ditjen P2P, Jakarta, 2017

[5] Kementerian Kesehatan, Situasi dan Analisis HIV AIDS, Pusat Data dan Informasi Kementerian Kesehatan RI, Jakarta, 2014.

[6] Dzokoto, A National Report on the Progress of the United Nations General Assembly Special Session (UNGASS) Declaration of Commitment on HIV and AIDS, Ghana Aids Commission, Accra, 2008.

[7] Afrizal, Metode Penelitian Kualitatif: Sebuah Upaya Mendukung Penggunaan Penelitian Kualitatif dalam Berbagai Disiplin Ilmu, Raja Grafindo, 2015.

[8] Agustin, Hubungan antara Riwayat ASI, Pola MP-ASI, dan Penyakit Infeksi Terhadap Status Gizi Balita Usia 6-24 Bulan, Airlangga University Library, Surabaya, 2010.

[9] Kementerian Kesehatan, Pencegahan Penularan Ibu ke Anak (PPIA), Jakarta, 2013.

[10] Khachatryan, H, "Qualitative study to explore the knowledge and attitude of pregnant women regarding HIV/AIDS testing in Kotayk region and in Yerevan, Armenia”, Accessed from http://aua.am/chsr/PDF/MPH/2005/HenrikKhachatryan.pdf, 2008.

[11] Kanabus, A., \& Nobel, R., "Preventing Mother-to-Child Transmission of HIV", Accessed from www.aegis.com/news/ips/2004/IP040730, 2005.

[12] Sachabe, E.V, "Knowledge and Attitudes of Women Regarding Mother-to-Child Transmission of HIV Infection in the Ehlanzeni District, Mpumalanga Province, South Africa", in http://ul.netd.ac.za/bitstream/handle/10386/531/dissertation/sechabeev.pdf?sequence=1, 2011 .

[13] Tovio, A. "Perceptions and experiences of pregnant women towards HIV voluntary antenatal counselling and testing in Oshakati Hospital, Namibia", in http://etd.uwc.ac.za/xmlui/bitstream/handle/11394/1341/Toivo_MPH_2005.pdf?sequence=1, 2005.

[14] Kumar, A. \& St. John, M.A., "Knowledge, Attitudes, and Sexual Practice Among the HIV Infected Women with Repeated Childbirths in Barbados” in http://www.informaworld.com/smpp/content., 2007. 